\title{
Situating Zimbabwe's Natural Resource Governance Systems in History
}

Alois Mandondo 


\section{CIFOR}

CIFOR was established in 1993 as part of the Consultative Group on International Agricultural Research (CGIAR) in response to global concerns about the social, environmental and economic consequences of forest loss and degradation. CIFOR research produces knowledge and methods needed to improve the well-being of forest-dependent people and to help tropical countries manage their forests wisely for sustained benefits. This research is done in more than two dozen countries, in partnership with numerous parners. Since it was founded, CIFOR has also played a central role in influencing global and national forestry policies.

\section{CGIAR}

The Consultative Group on International Agricultural Research (CGIAR), established in 1971, is an informal association of nearly 60 public and private sector donors that support a network of 16 international agricultural research centers. The CGIAR's mission is to contribute to food security and poverty eradication in developing countries through research, partnership, capacity building and policy support. The CGIAR promotes sustainable agricultural development based on environmentally sound management of natural resources.

This publication is supported by

The Swiss Agency for International Cooperation 


\section{Contents}

$\begin{array}{ll}\text { Abstract } & 1\end{array}$

Introduction 1

What is to be decentralised, to whom, how

and with what effect? 2

What has to be entrusted?

Entrustments for whom?

Communities as 'ideal units' for decentralised natural

resource governance systems 3

When does a decentralised governance system
become 'effective'?

Mechanisms of transfer 4

Colonial ascendency and land apportionment 4

Indirect rule, native commissioners, chiefs and councils;

the first decentralisation? 5

The enduring legacy of discriminatory environmental conservation

$\begin{array}{ll}\text { Forging governance institutions in the post colony } & 10\end{array}$

$\begin{array}{ll}\text { Crafting local government from colonial forms } & 10\end{array}$

The disempowerment and subsequent courtship of chiefs 12

$\begin{array}{ll}\text { Discussion } & 14\end{array}$

$\begin{array}{ll}\text { Acknowledgements } & 16\end{array}$

$\begin{array}{ll}\text { References } & 16\end{array}$ 


\title{
Situating Zimbabwe's Natural Resource Governance Systems in History
}

\begin{abstract}
Alois Mandondo*
Abstract

This paper reviews natural resource governance in Zimbabwe's peasant sector from colonial to post-colonial times. Governance is considered within the framework of power, process and practice and how these shaped peasant access, control and use of natural resources. Colonial natural resource governance systems resulted in over-centralisation because they were crafted in the context of conquest and subjugation. Over the years, state visions of appropriate management and use of resources have largely been extended to the African peasant sector through a centrallydirected structure and process. However, state control over the use and management of resources among the peasantry was and is largely ineffectual because the state lacks the resources and capacity to enforce such controls. Much of the colonial legislation was inherited piecemeal into post-colonial times, and amendments to date have largely deracialised the colonial acts and policies without democratising them. Pioneering efforts at decentralising entrustments over use and management of resources to the peasant communities have largely resulted in recentralisation at the district level, where such efforts are still practised in the trickle-down mode. This is in part because the policy thrust seeking to empower the peasant communities is supply-led, and thus defined according to the terms and processes of external agents, including funders and central governments and their functionaries. The study argues that supply-led decentralisation needs to be complemented by demand-driven decentralisation.
\end{abstract}

\section{Introduction}

This paper reviews natural resource governance in Zimbabwe's peasant sector from colonial to post-colonial times, with special emphasis on woodland resources. Although the review focuses on woodlands in the Zimbabwean peasant sector, it could not necessarily be restricted to that sector alone since woodland governance is intricately linked with other components of social and ecological systems in which it operates. Governance is considered within the framework of power, process and practice and how these have shaped access, control and use of natural resources. The framework recognises that although people or structures may wield power, the exercise of such power is usually mediated by a variety of factors, including those grounded in the contexts in which the power operates (Moore 1996). The mediation of power through a variety of factors is usually a reflection of the contestation and negotiation of interest between and within various levels of society (Hasler 1993). This paper analyses some of the interests that shaped natural resource governance systems for the Zimbabwean peasant sector. The analysis situates contemporary patterns of peasant access, control and use of resources within a deeper historical perspective as done and argued for in a number of other studies (Berry 1989, Moore 1993, McGregor 1995).

The second section presents a theoretical treatment of the policy thrust seeking to empower peasant communities through decentralised entrustments to the use and management of natural resources. A careful examination of what is being decentralised to whom, how and with what effect shows that decentralisation can have very little to do with democratisation of forest management. The third and fourth sections outline and analyse events leading to the over-centralisation of the country's natural resource governance systems, despite rhetoric implying decentralised, democratic governance, and how this impinged on peasant access to natural resources. The colonial state was imposed from outside on the basis of conquest and subjugation, and it was founded upon the expropriation of land, resources and power from indigenous communities. Colonial administration was extended over the African peasantry through a system of indirect rule of chiefs and allied 'traditional' institutions, presided over and controlled by European native commissioners. Colonial administration was one of patronising goodwill and benign neglect and it, over time, resulted in the weakening of the African sector.

\footnotetext{
* Institute of Environmental Studies, University of Zimbabwe and Center for International Forestry Research. E-mail: mandondo@africaonline.co.zw
} 
The fifth section outlines the evolution of centrally-directed legislative controls, most of which were implemented in a highly authoritarian manner. The section also outlines how key elements of colonial legislation were adopted piecemeal by post-colonial regimes under which later amendments largely deracialised the colonial acts and policies without democratising them. The section shows that the few natural resource governance policies seeking to extend the benefits of management of natural resources to local communities have resulted in recentralisation at the district level, where they are still largely practised within a top-down mode. The sixth section of the study argues that although local government reform in the postcolonial period was purportedly adopted to give a democratic orientation in planning for local development, such reforms neither decentralised nor democratised local government. Instead, such reforms appear designed to ensure one-party political domination. Meanwhile, the report will also show that the role of chiefs and allied traditional institutions as 'custodians' of culture has never been reformed from colonial through to present times, but the chiefs have experienced fluctuating fortunes at the altar of political expediency.

The last section argues that policies seeking to empower peasant communities to the benefits of use and management of natural resources through decentralised 'entrustments' are still enacted in a top-down manner. The decentralised entrustments are defined according to the terms and processes of external agents, including funders of projects and central government and their functionaries. The study concludes that supply-led decentralisation needs to be complemented by demanddriven decentralisation, conceivably championed by civil society, to ensure genuine democratisation and empowerment in natural resource management.

\section{What is to be decentralised, to whom, how and with what effect?}

\section{What has to be entrusted?}

A huge body of literature has accumulated on what exactly the central state should entrust among aspects of the governance of forest resources (Conyers 1990, de Valk 1990, Wekwete 1990, Murombedzi 1991, MutizwaMangiza 1991, Mamdani 1996, 1999, Makumbe 1998, Ribot 1999a 1999b, Schroeder 1999). Meinzen-Dick and Knox (1999) have attempted a distinction of what could be transferred from states to other actors in their peripheries using a property rights approach similar to the one developed by Ostrom and Schlager (1996). They show that states can give up some of the following sets of rights over resources: access - rights to enter a physically defined area to enjoy non-subtractable benefits; withdrawal - rights to obtain units of a resource; management - rights to regulate internal use patterns and to direct day to day stewardship; exclusion - rights to determine who has access; and, alienation - rights to sell or lease management or exclusion rights. The conferment of any of the above rights on specific actors, however, also places obligations on other actors to recognise such rights. In practice, people often use and assert claims to resources that they are neither entitled to own nor manage. Rights are, therefore, usually only as secure as the extent to which others are willing to recognise them (sensu Frost and Mandondo 1999). Understanding the effectiveness of the transfer of rights from states, therefore, takes much more than a mere characterisation of the specification of the rights. More important is how such specifications mirror against praxis in everyday social practice, and how such practice and the structure of rights shape each other (Hesseling 1996, Gupta 1999, Li 1999). In spite of its merits, an over-emphasis on rights runs the risk of ignoring other factors such as capacity, assets, resources and decision-making autonomy, which are all critical components of an effective entrustment process ${ }^{1}$ (Hesseling 1996, Ribot 1998, Vermillion 1999, Agrawal and Ostrom 1999). A meaningful and comprehensive entrustment must include these factors as well.

\section{Entrustments for whom?}

In addition to looking at the content of the entrustments, natural resource governance studies have also considered which units should be entrusted with various aspects of forest governance (Conyers 1990, Murombedzi 1991, Murphree 1991). In practice it is not easy to draw neat lines between the state and a variety of other actors in its fringes such as provincial and district administrations, local governments, the local 'communities' at the grassroots level, and perhaps, to a smaller extent NGOs. Overlaps $^{2}$ between these structures are such that they are often best conceived as state-local continuums (Murombedzi ${ }^{3}$, personal communication). Globalisation in the arena of the environment has, at a broader level, entailed expanding partnerships that have blurred the demarcations between states and actors lying beyond them, including international associations, funders, lobbies and NGOs (McNeely 1995). Entrustments may thus be distributed to a range of actors, especially along the state-local continuum.

\footnotetext{
${ }^{1}$ Entrustment is used to refer to the size and content of the package of powers, responsibilities and authority transferred from one level of social organisation to another.

${ }^{2}$ Hesseling (1996) argues that over the years, states and organisations on their fringes have penetrated and contaminated each other to the extent that 'there is some statishness in the local, and also much that is local in the state'.

${ }^{3}$ James Murombedzi, Ford Foundation, Johannesburg, South Africa.
} 
Decentralisation describes the process by which bundles of entrustments, including regulatory and executive powers, responsibility and authority in decision making, institutional infrastructure and assets, and administrative capacity, are variously transferred to local groupings, e.g. local governments or communities (Crook and Manor 1998, Agrawal and Ostrom 1999, MeinzenDick and Knox (1999), Pomeroy 1999). Decentralisation can either occur through deconcentration or devolution. In deconcentration central governments are simply made smaller by the transfer of some entrustments to branches of the government, which still remain responsible to central government (Ribot 1999a), often with the central government reserving the right to supervise, overturn or withdraw the entrustments (Pomeroy 1999). In devolution the entrustments are transferred more or less completely to the local users (Meinzen-Dick and Knox (1999). Privatisation involves the transfer of these entrustments from the public sector to the private sector (Meinzen-Dick and Knox (1999). The multiplicity of terms in the vocabulary of transfer of entrustments from states reflects both the complexity and patchiness of the process (Pomeroy 1999). Devolution is the mode of decentralisation considered in this study, but the term 'decentralisation' will be used for purposes of consistency.

Practical engagement in everyday social practice may further add to the patchiness and complexity of decentralisation. Quite often, states aspire to extend their influence and control beyond ${ }^{4}$ where they lack the resources or the capacity for effectively asserting such influence (Murphree 1991). Actors on the fringe of formal systems of power often move in to assert territorial and other claims to areas in which governments are unable to exercise effective control. Access to natural resources is, in practice, therefore subject to multiple and competing formal regulatory and informal utilisation regimes (Metcalfe 1995). The formal and systematic process of transfer of power (de jure decentralisation) may have little to do with where effective control really lies (de facto decentralisation) (Pomeroy 1999). It is within this complex maze that the 'ideal units' for decentralised natural resource management have to be conceptualised.

\section{Communities as 'ideal units' for decentralised natural resource governance systems}

Taken simply, the most appropriate units are those that define users of resources as owners and managers of the resource so that the costs and benefits accrue directly to them. These units are often called 'communities'. Claims that communities are the best units to govern resources are inspired by the appeal of 'smallness', with identifiable groups of interdependent users sharing common interests, norms and beliefs (McCay and Acheson 1987, Berkes and Farvar 1989, Ostrom 1990). Such units are seen as being more organisationally cost effective, since they have shared norms allowing for informal peer pressure to reduce transaction costs. An instrumental ${ }^{5}$ assumption often made is that packaging ownership, management and use of resources into such units will provide an incentive for better management of the environment (Madzudzo 1999; Murphree 1999). Since the 1980s, such images of community have found their way into common usage in environment and development planning, and emerging experiences have proved to be both 'enchanting and disenchanting' (sensu Agrawal and Gibson 1999).

The enchantment of community lies in its appeal as a potentially more ethical and effective alternative to state-directed management of natural resources. An international 'back to the people' movement has become associated with this set of expectations, i.e. the promise of community and its potential role in environmental management (IUCN 1980 1991, WCED 1987, UNEP 1992). Development plans based on idyllic images of community have, however, largely performed far below expectations, and disenchantment is increasingly prevalent. Much of the failure reflects the fundamental contradictions between planning on the basis of assumptions of homogeneity and fixity in an otherwise complex and dynamic world (Berry 1993, Scoones 1996). Customising ${ }^{6}$ plans to prevailing complexity is a step towards addressing this problem. In the case of Zimbabwe such failure cannot necessarily be attributed to flawed conceptions of community alone but also to the failure by the state to genuinely devolve effective entrustments to the 'communities' (Murombedzi 1992). Resolving the dilemma of community therefore needs to be addressed together with the problem of the exclusion or marginalisation of the communities from the management of local natural resources.

\section{When does a decentralised governance system become 'effective'?}

Planning decentralisation within arenas with multiple and often competing actors and interests goes beyond the mere specification of entrustments or targeting appropriate 'communities' (Ribot 1999a). Political elites play the

\footnotetext{
${ }^{4}$ The straying of the state beyond zones of its effectiveness has been portrayed as 'the state's hand extending beyond its grasp' (Murphree 1991).

${ }^{5}$ Unlike Namibia's LIFE programme which uses social empowerment as an entry point to decentralised natural resource management, Zimbabwe's CAMPFIRE programme uses economic benefit as an entry point to getting communities interested in natural resource management. CAMPFIRE is therefore based on instrumental assumptions that economic benefit is an instrument for community participation and that such participation will lead to better environmental management.

${ }^{6}$ The main argument in Leach et al. (1997) also supports this thrust, as does the argument by $\mathrm{Li}$ (1999).
} 
power game to their own advantage in communities characterised by power asymmetries. For instance, Mukamuri (1995) shows how territorial power elites in south-central Zimbabwe monopolise access to 'sacred forests' by manipulating rules in such a way that they are inclusionary in respect to cost, but exclusionary in respect to benefit. Marindo-Ranganai and Zaba (1995) also show how power imbalances between the Shona and the Tembomvura have translated into ethnically-based inequalities of access to resources in the Zambezi valley. Findings from another study, conducted in western Zimbabwe, show how differences in asset endowments across three ethnic groups translate into power imbalances and inequalities of access to resources, with the more powerful groups privileged in each case (Madzudzo 1999). Communities are also highly differentiated along several other axes: gender (Berry 1989, Fortmann and Nabane 1992); asset endowments, e.g. cattle, oxen and ox-carts (Jackson 1989, Muchena 1989); educational levels and length of residence in the area (Nhira 1994, 1998); and in general, socio-economic status (Shipton and Goheen 1992, Price and Campbell 1998).

In view of the fact that actors in governance systems are variously differentiated, decentralisation should be representative in order to cater for multiple interests and aspirations, since everybody cannot participate in governance on a day-to-day basis (Ribot 1999a). Transparent electoral processes are a central facet of representation (Hesseling 1996) but they are not enough on their own since governance systems often turn out to be representative only in form and not in spirit. There needs to be downward accountability between representatives and the represented to ensure public participation in decision making (Ribot 1999a). There, as yet, appears to be no standard toolkit of objective measures to assess accountability in natural resource governance systems. Ribot (1999b) has collated a long, if cumbersome, checklist of criteria from the literature including: transparent electoral systems; legal recourse through the courts; third party monitoring by media, NGOs and advocacy movements; political pressures and lobbying by associations; access to information on the roles and obligations of government; embeddedness of leaders in their communities; civic dedication and pride of leaders; orchestrated participation; social movements; threats of social unrest; threats of resistance; central state advocacy for citizen rights, etc.

Goals of decentralisation may, however, differ from time to time and from one governance system to another, which implies that menus of criteria for accountability are best not conceived in a static perspective. For instance, the accountability criteria for Namibia's LIFE programme, where decentralisation is a paradigm of social empowerment, are quite different from those of Zimbabwe's instrumental CAMPFIRE programme (Child 1993). The CAMPFIRE philosophy sees decentralisation as providing tools (economic incentives) to facilitate the involvement of the communities in conservation of natural resources (Child 1993). In the LIFE programme, empowerment, with attendant environmental spin-offs, is an end in itself and the criteria for evaluating accountability are mostly socially oriented. In CAMPFIRE there are accountability criteria traversing the entire spectrum from the economic to the social, to the environmental.

\section{Mechanisms of transfer}

Instruments and processes through which entrustments are decentralised may also have implications for accountability and public participation in decentralised systems. Authority can be decentralised to lower units either through legal specifications or through political/ administrative directives. Legal entrustments generally take longer to enact, amend or repeal, but their fate is usually subject to comparatively broader and more transparent scrutiny than political directives (de Valk 1990). If shorter red tape is the virtue of political directives, then arbitrariness and opacity may be their vices, especially in systems where officials enjoy broad discretionary powers (Thompson and Freudenberger 1997). Both legal and political directive ways of decentralising entrustments are fraught with the dangers of top-down and trickle-down orientations. States and other external actors have largely adopted postures and approaches that suggest implied or explicit intentions to direct the process of decentralisation instead of facilitating it (de Valk 1990, Hawkes and Madzudzo 1991, Dzingirai 1995, Schroeder 1999). There is a tendency, in bureaucratic hierarchies for actors to seek more power from levels above, and a general reluctance to devolve such power to levels below (Murphree 1991). Actors within state hierarchies also tend to decentralise service-type activities whilst retaining control of fiscal and production-oriented activities (Conyers 1990, Murombedzi 1991). The problem faced in creating greater local participation in resource management is, therefore, not just about fostering its beginnings, but identifying and dismantling structures that may, from time to time, detract from the achievement of genuine participation (de Valk 1990).

\section{Colonial ascendency and land apportionment}

Decentralisation enjoys broadest moral and ethical appeal in Africa, and elsewhere, where states were imposed from the outside on the basis of conquest and subjugation (Wekwete 1990, Hesseling 1996, Marcussen 1996). Having been founded on the basis of conquest, colonial rule was subsequently consolidated on the basis of expropriation of power and resources (land, labour, 
capital e.g. cattle, taxes) from customary systems to emerging state/capitalist forms (Wekwete 1990). Colonial rule further secured itself by inserting itself into many facets of the lives of the conquered communities resulting in the over-centralised states that were to be inherited by post-colonial governments. States in most post-colonial countries still carry an imperialist stigma because of their origins in external imposition, and in over-centralised structures in which power was formerly organised along racial lines (Mamdani 1996). The power structures were often perpetuated to entrench the interests of certain segments of post-colonial society, particularly the ruling class (Hyden and Bratton 1992, Marcussen 1996, Medard 1996, Makumbe 1998). The ideology of decentralisation, therefore, carries enormous emancipatory appeal in such settings.

Traffic between early peoples, in what was to become Zimbabwe, and European explorers, traders, hunters and missionaries spans back to as early as the $16^{\text {th }}$ Century (Beach 1980, Mashingaidze 1984). Except for occasional slave raids and instances of missionaries being killed, early forms of interaction generally remained of a benign nature. The 1890s brought the colonial encounter characterised by conquest and subjugation of the indigenous communities by the British South Africa Company (BSAC) operating under licence of a royal charter granted by the imperial power, Britain. A central feature of the expansion of settler rule under the BSAC was the expropriation of land and other assets (e.g. livestock) from the indigenous communities. Fading hopes of discovering new gold deposits forced more and more settlers to turn to agriculture, and this reinforced the process of alienation of land and resources from indigenous communities (Phimister 1988, Murphree and Cumming 1991). The process of land alienation culminated in its formal apportionment in 1930. Prime land, mostly in high potential agricultural zones, was parceled out to European settlers under freehold and leasehold arrangements. Indigenous communities were forced into native reserves, mostly in marginal and low potential areas of the country where they were to exist under a system of customary tenure (Grant 1976, Moyo et al. 1991, Moyo 1996a). The legacy of racial imbalances in the distribution of land has endured into the $21^{\text {st }}$ century, and the 'land question' remains one of postindependent ${ }^{7}$ Zimbabwe's major challenges.

The execution of the colonial project, a century earlier, had to find a place for the African in the process of land alienation. Imperial (British) colonial design, from the 1890 s up to 1923 , is said to have favoured a humane colonisation process in which alternative land was to be provided to Africans displaced from alienated lands (Holleman 1968, Weinrich 1971). Holleman (1968) holds that the BSAC could easily manipulate such imperial 'good intent' towards the interests of settler colonial expansion because such good intent was directed from afar. Local scholars argue that settler colonial expansion was, in fact, part of the imperial colonial design given the short period in which the BSAC became an autonomous government (Mashingaidze 1984, Manungo 1991). An order-in-council granted by the British government confirmed de facto government of the company after the suppression of the Ndebele and Shona rebellions of 1896-7. By 1923, the settlers were allowed to take over government but they were to put in place a cadre of native commissioners to advance African interests (Holleman 1968). The native commissioners became institutions through which colonial authority and control were extended to Africans in the so-called native reserves through a system of indirect rule.

\section{Indirect rule, native commissioners, chiefs and councils; the first decentralisation?}

Colonial administrations often justified indirect rule in terms not unlike those advocating decentralisation today: respect for local cultures; fiscal accountability; and giving people a voice in their own governance. Indirect rule, however, was very much about extending the power of the central state. Interpreting the lessons from this era helps clarify the shortcomings of today's decentralisation policies.

Instead of dismissing African cultures offhand, architects of colonial rule sought to understand and permeate such cultures in order to discipline the Africans into the project of colonial administration (MutizwaMangiza 1985). People manning the frontlines of colonial administration in African areas were expected to be particularly adept at understanding the ways of Africans, for ease of incorporation into grassroots extensions of colonial rule (Holleman 1968, Weinrich 1971). Meanwhile, early missionaries and anthropologists had made pioneering forays penetrating deeper into peasant life and through their liturgical and scientific projects played the role of surveillance and eavesdropper institutions (Bhebe 1979, Bourdillon 1991, Zvobgo 1996). Such forays provided detailed systems of knowledge on African life which native commissioners could easily tap.

'African interests' were largely advanced through hereditary chiefs and allied traditional institutions, e.g. headmen and kraalheads, presided over by the native commissioners (Holleman 1968, Weinrich 1971). Although chiefly power was hereditary, native commissioners enjoyed the discretion to create, co-opt

\footnotetext{
${ }^{7}$ Zimbabwe became independent on $18^{\text {th }}$ April 1980.
} 
and legitimise chiefly authorities most suitable for the interests and designs of colonial rule (McGregor 1991). Duties such as the collection of taxes on behalf of the colonial administration, control over the allocation of land in the reserves, presiding over land disputes, local custom and tradition were some of the 'African interests' advanced through the institution of colonial chiefs (Mutizwa-Mangiza 1985, Mcgregor 1991). As indirect rule for natives was being crafted, European citizens enjoyed the benefits of direct rule including a system of rights guaranteeing free enterprise, recourse to justice, electoral privileges, and a system of governance based on the separation of powers. In distinguishing between the two systems of power, Mamdani (1999) terms indirect rule a decentralised despotism, because:

'Hereditary and administratively appointed chiefs were privileged as the traditional institutions whose interpretation of custom should hold sway over that of every other institution in traditional society ... and the chiefs were defined on the basis of masculinity, seniority and caste....such that from a multiplicity of contending versions of custom, a single version was sanctified as official'.

From then on traditional chiefs occupied a prominent part of the governance landscape in African areas where they enjoyed fluctuating fortunes well into post-colonial times (Scoones and Matose 1993). Over the years, chiefs have been alternatively empowered and disempowered in various roles as extensions of colonial rule, conservation allies and sources of political mileage (Holleman 1968, Weinrich 1971, Mutizwa-Mangiza 1985, Scoones and Matose 1993). Earliest forms of statesanctioned governance structures in African reserves were native boards, consisting of chiefs and headmen and an equal number of literate Africans (appointed by the native commissioner) to represent the interests of the educated sector ${ }^{8}$ within the African peasantry. More elaborate forms of African local government were established following the enactment of the Native Councils Act in 1937 (Holleman 1968, Mutizwa-Mangiza 1985). The councils again consisted of chiefs and headmen and other Africans appointed by the native commissioner from nominations by local communities. The native councils were intended to ensure more effective group action and were presided over by the native commissioner. Such earlier local governance bodies were largely ineffectual because they had no budgets, while their mandates were broad and vague. Despite a patina of local accountability, both native councils and African boards were controlled by native commissioners and acted as conduits of colonial rule (Mutizwa-Mangiza 1985).
Native councils were reconstituted into African councils and vested with statutory power to impose rates, collect taxes and enact locally binding by-laws by the African Councils Act of 1957. In addition to chiefs and headmen, African councils consisted of popularly elected members, but they were presided over by native commissioners (Holleman 1968, Weinrich 1971). Despite the privilege of revenue collection, the councils remained very under-funded because of the skewed distribution of colonial allocation of public sector capital investment (Mutizwa-Mangiza 1985, Wekwete 1990). The provision relating to by-laws was partly informed by conservationist alarm about environmental degradation in African reserves, which came to prominence around the $1950 \mathrm{~s}$, designed to shore up local support for environmental restoration, rather than to give voice to local environmental concerns (McGregor 1991). The Native Land Husbandry Act of 1952 had meanwhile transferred land allocation powers from chiefs to the state to give the state a better handle of addressing the 'looming' environmental disaster in the African reserves. Environmental restoration was stiffly opposed in the reserves because it entailed the destruction of African capital (e.g. destocking), and it was carried out in a highly authoritarian manner (Scoones and Matose 1993, McGregor 1995). This opposition fed into the growing nationalist movement and helped fan resistance against white rule, forcing the abandonment of coercive environmental restoration towards the end of that decade (Makumbe 1998).

Chiefs were to feature quite prominently again in the 1960s when they were courted by the Rhodesia Front government to shore up legitimacy for the internationally isolated Unilateral Declaration of Independence regime, and to stem the nationalist tide (Holleman 1968, Mutizwa-Mangiza 1985). The courtship saw chiefs recuperating their land allocation powers through the Tribal Trust Lands Act of 1967, which also saw African reserves renamed Tribal Trust Lands (TTLs). Earlier in the decade both chiefs and councils had been courted into a new development dispensation called the community development approach for the African reserves. The approach envisaged a holistic approach to developing a broad range of community capacities (technical, human, financial, etc.), and securing the participation of communities for well coordinated and

\footnotetext{
${ }^{8}$ Parallel to the process of crafting indirect rule, colonial rulers also sought to abstract amenable groups of civilised people from the peasantry, and these groups enjoyed restricted forms of European privileges e.g. 'master farmers' who obtained land under leasehold or freehold in the then Native Purchase Areas (Murphree and Cumming 1991).
} 
integrated rural development (Mutizwa-Mangiza 1985). Despite generous funding from USAID, the approach registered limited impact given the immensity of the need arising from decades of colonial neglect of the African tribal areas. From the perspective of democratic representation at local level, the initiative was mainly driven through councils whose members were accountable to native commissioners and not to local communities. The African councils had no autonomy because of close supervision by native commissioners and the central government field administration (Helmsing 1991). At a broader level, the initiative was a failure because it proclaimed democracy at the local level whilst denying democracy to the majority at the national level (Mutizwa-Mangiza 1991). The initiative, however, resulted in the multiplication of African Councils. No less than 200 such councils, in one form or another, survived into post-colonial Zimbabwe (Makumbe 1998). Towards the end of the 1970s most of the councils had almost collapsed because of the escalation of the war. The tribal lands became fragmented into zones of shifting control between the Rhodesian military wing and the mass mobilisation committees of the guerilla movement (Lan 1985, Godwin 1996).

Colonial neglect of African reserves was the result of a fiscal apartheid in public sector capital investment policies (Wekwete 1990). The bulk of the social and physical infrastructure investment was located in European areas to support a fledging capitalist economy, which was further supported with much subsidy and preferential marketing policies (Murphree and Cumming 1991, Scoones and Matose 1993, McGregor 1995). Under-investment in the African reserves reinforced the under-development of the peasant sector, which remained a source of cheap labour for the emerging capitalist economy. Over time the peasant sector was also weakened by the downstream effects of the communal tenure system under conditions of high population growth, including lack of collateral, subdivision into smaller and smaller holdings, low productivity and declining surpluses, and very low propensities to save and invest. The impoverishment of the peasant sector was further worsened by discriminatory marketing policies for some agricultural commodities (maize and cattle), low remuneration for wage labour, taxation, and forced landuse and environmental conservation measures (McGregor 1991, Scoones and Matose 1993).

Indirect rule was never intended to democratise resource governance and did not, despite language that might suggest otherwise. Central government created or reformed local institutions and kept them under tight administrative and fiscal control. Little effective decentralisation occurred, and would not within a racial rule framework.

\section{The enduring legacy of discriminatory environmental conservation}

Both the neglect of the African sector in the overpopulated reserves and the expansion of agriculture and mining in the European sector entailed changes in landuse and related changes in the state of the environment. A settler colonial mindset framed on experiences with environmental crises within and beyond ${ }^{9}$ the empire interpreted the environmental changes with considerable alarm. Conservationist concern justified state intervention and inspired the beginning of centralised forms of environmental regulation, especially for native areas. Over the years state visions of appropriate management of resources have been extended to peasant communities through a top-down structure and process (Scoones and Matose 1993).

Earliest forms of control in the woodland sector aimed at curtailing unprecedented woodland depletion associated with the opening up of land for settler agriculture and wood extraction for the energy and timber needs of the tobacco and mining industries (McGregor 1995). The colonial state imposed fees for the extraction of timber from mining zones but the mining contractors avoided such tariffs by extracting wood from native reserves, in response to which the Native Reserves Forest Produce Act of 1928 was enacted. The act provided for the following: regulation of timber concessions to native reserves through Native Commissioners; prohibitions on tree felling for any purpose other than subsistence; and protection of certain tree species from felling. Restrictive controls on access to timber in native areas faced strong opposition from the mining and tobacco growing lobbies which only subsided in the 1940s when wood was replaced by coal and electricity as alternative energy sources (McGregor 1995). Also, the colonial form of the act could not effectively protect peasant communities from European competition for timber. Native Commissioners often offered timber to the miners at concessionary rates in affirmative recognition of the mining industry's contribution to overall development (Scoones and Matose 1993).

The act restricted the range of uses to which peasant communities could put their woodlands despite the envisioned merits of protecting native reserves from external competition for timber,. The anti-commercial sentiment of the act assumed peasant production systems were 'frozen' subsistence forms (Berry 1993, Fairhead and Leach 1995). This sentiment has become

\footnotetext{
9 Experiences with deforestation were mainly borrowed from India while the American Dust Bowl later provided experiences on soil erosion and soil conservation (Beinart 1984; Scoones 1996).
} 
anachronistic among peasant communities that have increasingly become integrated into broader global/ national economies. Despite some cosmetic amendment in 1987, the colonial provisions of the Native Reserves Forest Produce Act still remain intact, making a mockery of the post-colonial state's commitment to democratise the country's natural resource governance systems.

The Forest Act of 1948 (amended 1982) provided for the establishment of production and protection managed by the state for the conservation of biological diversity, watershed management and commercial hardwood extraction. The act also vested the state forestry agency with the power to regulate the exploitation of indigenous hardwood timber from peasant areas, with the revenue accruing to Rural District Councils. Murphree and Cumming (1991) call this act a double expropriation, where peasants are disempowered through displacement from the land, and the loss of control over resources in areas in which the peasant communities were relocated. However, the production and protection forests are not entirely free from tenurial and other pressures (Nhira et al. 1998). Most are surrounded by peasant communities or share common boundaries with them. Peasant communities in areas adjacent to state forests often settle on the protected lands or use resources from them, despite state prohibitions on such activities. The state lacks the capacity and resources to enforce such prohibitions. People use resources in protected areas for a variety of reasons, including: the relative abundance and nearness of resources in the protected areas; historical and ancestral claims on the protected lands; and, incitement by powerful politicians, who usually move in to assert grazing rights when peasants 'liberate' such lands (Catholic Commission on Peace and Justice 1992, Nhira et al. 1998). Attempts to evict 'squatters' from protected areas have usually faced resistance from the settlers themselves. Such evictions duly receive condemnation from human rights watchdogs, especially when neither alternative land nor humanitarian assistance is provided to the evicted families (Catholic Commission on Peace and Justice 1992). Formulations that seek to involve peasant communities in the use and management of resources in protected areas are receiving pioneering attention but their efficacy is still to be felt (Matzke 1993, Nhira and Matose 1995).

The Natural Resources Act of 1941 provided for the establishment of the Natural Resources Board, a national conservation watchdog comprising stateappointed members. The act vested the board with broad and sweeping powers of intervention in the area of environmental conservation, and in native areas these powers were exercised in a capricious and arbitrary manner: forced soil conservation works often relying on forced labour; restrictions on grazing; compulsory destocking; restrictions on cultivation, e.g. within 30 metres of water bodies; restrictions on cutting of trees; and forced controls on excavation and building (Scoones and Matose 1993). In addition, the act vested the president with powers to designate any piece of land in peasant areas for resource preservation. In European areas, the enforcement of the provisions of the Natural Resources Act relied on voluntary regulation and the investment of large-scale grants, loans, machinery and other incentives to assist white settlers in implementing conservation measures (McGregor 1991, Scoones and Matose 1993). Voluntarily constituted conservation fraternities in European farming neighbourhoods received the designation of Intensive Conservation Areas (ICAs), which entitled their members to enhanced subsidy, land tax exemptions and pricing bonuses on agricultural produce (McGregor 1995).

Despite 25 post-colonial amendments, the Natural Resources Act still provides for a command and control approach to conservation among peasant communities (Scoones and Matose 1993). Amendments to the act reflect a woeful lack of democratic inspiration as is evidenced by the continuing exclusion of peasant communities from the benefits of voluntary conservation, and systems of incentives to promote such conservation. Criminalising provisions of the act contradict the spirit of freedom espoused during an independence struggle to bring an end to systems of oppression entrenched in the act. In addition, the Natural Resources Board is not constituted in a way to make it accountable to the local communities, where its policies are felt, but to the president to whom the members owe allegiance through appointment. Overall, the act is supposed to be the supreme environmental law with which ancillary environmental provisions scattered across over 36 acts are consistent. The provisions of the Natural Resources Act, however, do not specify a legal hierarchy to ensure consistency between the acts.

A current draft Environmental Management Bill seeks to rationalise the country's fragmented environmental laws by integrating them to ensure consistency with each other. A close follow up on the evolution of the bill demonstrates how a patronising posture has been ingrained into the country's legislative culture. The first draft of the Environmental Management Bill (by a consultant on behalf of the ministry) was very democratic with regards to natural resource governance among peasant communities. It sought to extend 'appropriate authority' to user-defined groups at the subdistrict level, and not to Rural District Councils alone. The democratic element envisioned in the draft appears to have been subverted in the Attorney General's Office. The legal draft of the Environmental Management Bill, emerging from that office, reversed most of the democratic provisions of the layman's bill. In most cases, the 'people' in the layman's bill was replaced by 'the 
president or the minister' in the legal bill, whilst appropriate authority to user groups was replaced by the status quo (appropriate authority to Rural District Council). It is highly unlikely that the democratic element will claw its way back into the final bill given the postcolonial legislative tradition in which the de facto oneparty parliament simply rubber stamps the decisions of the executive arm of the state (Makumbe 1996). As illustrated later, the problem is not with the Environmental Bill per se but with the structure of accountability in the Rural District Councils, which the bill seeks to further empower.

The Parks and Wildlife Act (1975 and amended 1982) is an example of a decentralisation thrust that specifically sought to deracialise access to resources by extending the benefits of resource conservation to people directly living with the resources. The 1975 version of the act restricted the benefits of the custodianship of wildlife resources to owners of alienated land, who were designated as appropriate authorities. Owners of alienated land translated into settler farmers enjoying individual title over land. A 1982 amendment extended the benefits of the act, through the CAMPFIRE programme ${ }^{10}$, to peasant communities in wildlife-rich areas by conferring appropriate authority status to Rural District Councils in which such communities lived.

The Parks and Wildlife Act is one of several acts vesting legal entrustments in the Rural District Councils and not in units closer to the citizens ${ }^{11}$. The Rural District Councils have decentralised cost-type activities, such as monitoring and enforcement, to local communities. However, the councils, together with other external actors, e.g. safari operators and the Department of National Parks and Wildlife Management, still retain effective control over the setting of hunting quotas, awarding hunting and other licences, and control over wildlife revenues (Murombedzi 1991, 1992). CAMPFIRE guidelines specify that at least $50 \%$ of the wildlife revenues should be devolved to the 'producer communities' but in practice, the revenues often come far too late, or in inadequate amounts, or both (Murombedzi 1994). Council reluctance to decentralise both the funds and the control of such funds is underlain by various factors. Not least of these are the funding limits imposed by the structural adjustment programme. Also, the Rural District Councils strongly sell their visions of how the community wildlife revenue dividend should be disposed. Senior government officials, particularly district administrators, governors and ministers, often inculcate the wisdom of channelling the funds into development projects (Murombedzi 1991). The advice may be well intentioned, but far too many voices from strong external constituencies often serve to reinforce the top-down orientation of the programme.
The Rural District Councils Act of 1988 eliminated and deracialised the colonial dualism in local government structures by combining them into a single system of local government. It amalgamated Rural Councils (formerly representing settler land owners) and District Councils (formerly representing interests of blacks in communal areas) into Rural District Councils under the Ministry of Local Government and National Housing. Among the numerous entrustments it conferred upon Rural District Councils was the power to enact legally binding landuse and conservation by-laws that apply to areas under their jurisdiction. Rural District Councils have the option of formulating the by-laws with the participation of local communities or adopting model by-laws from the Communal Land (Model Landuse and Conservation by-laws 1985). Model by-laws provide for the preparation of landuse plans in council areas and are similar to those promoted by the state in the $1930 \mathrm{~s}$ (Scoones and Matose 1993). They are based on a landuse planning system which makes use of aerial photographs to divide landscapes into an eight-class system of land units, with a matching portfolio of prescriptions of suitable uses for each unit. The landuse planning template is not only static but too generic for dynamic natural environments that exhibit considerable micro-variability (Scoones 1996). The plans often do not accord with the coping strategies of peasant communities in areas for which they are designed (Scoones et al. 1996). Also, bylaws formulated with the 'participation' of communities do not turn out to be appropriate. In practice, the bylaws are formulated by bureaucrats and technocrats at the district, and only thoroughly scrutinised for endorsement by higher provincial officials and the minister, and not by the local communities for which they are meant. Local communities are, however, afforded the chance to inspect the by-laws and, if necessary, lodge objections. Communities rarely inspect the by-laws partly because they are left out of the formulation process, whilst the by-laws themselves can only be inspected at the district or in obscure sections of newspapers that peasants cannot easily access, let alone read (Chagonda, personal communication ${ }^{12}$ Communities are, nevertheless, expected to cooperate with council monitors who enforce the by-laws and impose fines on violators, with the revenue accruing to the council. Levels of fines are arbitrarily pegged by the councils and not

\footnotetext{
${ }^{10}$ CAMPFIRE is an acronym for Communal Areas Management Programme for Indigenous Resources. It is premised on the concept that 'producer communities' or the basic units of social organization in wildlife rich areas should be empowered to use and manage the resources.

${ }^{11}$ Schilling (1995) argues that placing jurisdiction closer to the citizens is fundamental to the fulfilment of basic justice.

${ }^{12}$ Chagonda, E. Chief Executive Officer, Chivi Rural District Council.
} 
indexed to levels of community outrage or anger to various forms of breach, nor to community perceptions of the deterrence potential of various regimes of fines and the legitimacy of such fines. The fines siphoned by the councils from the communities usually fund recurrent expenditure at the district, instead of addressing the problems of environmental violations for which they are exacted. Thus, although the Rural District Councils Act deracialised local government it did not decentralise or democratise it. The act, in fact, recentralised power at district level, whilst making the exercise of such power unilateral, top-down and undemocratic.

\section{Forging governance institutions in the post colony}

\section{Crafting local government from colonial forms}

The post-independence government reconstituted over 200 colonial African councils into 55 district councils, each an apex of a local governance structure that encompassed peasant communities. Local government reform was largely inspired by the need to create a framework for expanded delivery of services to the peasant communities to redress the imbalances of colonial neglect (Helmsing 1991). The Prime Minister's directive of 1984 further outlined the structure through which peasant communities at sub-district level fitted into the district local governance framework. The directives created VIDCOs and WADCOs, units based on popular representation and envisaging a democratic orientation to the process of planning for local development. VIDCO is an acronym for village development committee. It is the lowest unit of government administration which is expected to identify the needs of the village and articulate the needs through the development of a local village plan. The VIDCO normally consists of 100 households, with slight variations from area to area, and it is presided over by an elected chairperson. WADCO stands for ward development committee, a body over-arching several VIDCOs, usually six per ward. The WADCO draws its membership from leaders of its constituent VIDCOs and is presided over by an elected councillor representing the ward at the district level. A ward development committee receives the plans of its constituent VIDCOs and consolidates them into a ward plan. Councillors then forward the plans to the district where they are submitted to the Rural District Development Committee ${ }^{13}$, the district's supreme planning body that is tasked with consolidating the various ward plans into the district's annual and five year plans.

Although the Prime Minister's directive gave peasant communities a system of representation in the process of planning for local development, political expediency subverted the democratic element of the system. Universal suffrage elects four of the six members of any village development committee. The remaining two positions are reserved for women and the youth, and are usually filled by members of the ruling party's youth and women leagues (Makumbe 1998). Two positions are also reserved for representatives of the ruling party's women and youth leagues in the ward development committees. Meanwhile the post of VIDCO chair is never regularly contested in democratic elections partly because there are no resources for such a process and also because the office is largely perceived by locals to be void and meaningless (Sithole 1997). Although local government elections for ward councillors are held regularly, they are conducted along political party lines. However, within the context of the country's prevailing de facto one-party state system ${ }^{14}$ the councillors owe allegiance to the ruling party's political elites, who endorse their candidature for the party's primary polls. The electoral system therefore largely churns out councillors who are upwardly accountable to their political benefactors and not downwardly accountable to their grassroots constituencies. In fact, the country's post-colonial electoral tradition has been such that a win in the ruling party's primaries usually guaranteed a walkover in the real elections. The infiltration of VIDCOs and WADCOs by the ruling ZANU-PF party has seen them carry the stigma of "politically sponsored institutions that have no clear bases in history, or mere grassroots extensions of the ruling party' (Matowanyika 1991). Although the Prime Minister's directive attempted to make governance structures representative it did not make them accountable, neither did it make them democratic. The outcome of the directives appear to share a common thread with the key features of colonial rule. They are the quest to discipline local institutions into certain forms of rule, racial domination during the colonial period and one-party political domination in the post-colonial era.

The Rural District Development Committee (RDDC) is chaired by the District Administrator, a government employee representing the Minister of Local Government and National Housing. Members of the RDDC include district heads of sectoral ministries, chairmen of the Rural District Council's various subcommittees, and district heads of national security

\footnotetext{
${ }^{13}$ After the amalgamation of Rural Councils representing European areas, and District Councils representing African areas into Rural District Councils, these supreme planning bodies became Rural District Development Committees.

${ }^{14}$ This system prevailed before the watershed parliamentary elections of June 2000, which brought a significant number of opposition legislators into parliament.
} 
organs, e.g. army, police and national intelligence (Thomas 1991, Makumbe 1998). Membership of the RDDC is thus almost exclusively restricted to bureaucrats and technocrats at the expense of 'popular' representatives of grassroots structures. Underrepresentation of grassroots structures in the district's supreme planning body attenuates the spirit of popular participation in planning for local development. It excludes communities from forums in which crucial decisions are made over grassroots visions and aspirations. Grassroots under-representation in the RDDC is further reinforced by lower literacy levels ${ }^{15}$ among community representatives in comparison to bureaucrats and technocrats. The presence of the police, army and national intelligence also provides an intimidating setting, given their role and history as instruments of state force and coercion. Because of its imbalances in terms of effective power and representation, the RDDC basically serves as a technical and bureaucratic referee and editor of purported grassroots plans. District Councils, as elected bodies, are meant to approve plans before they are forwarded to provincial councils, provincial development committees and national planning agencies. In practice, RDDCs effectively do the planning while the Councils simply approve plans for onward forwarding to the higher bodies (Makumbe 1998).

In principle, councillors should consult their constituencies for approval of the consolidated plans. The RDDC, however, perpetuates top-down orientations by providing a forum for development planners and administrators to mobilise local participation for the endorsement of RDDC-authored plans, and by legitimising such plans through shallow, hurried, dubious and cosmetic consultation processes (Murombedzi 1991, Makumbe 1998). Instead of providing accountable representation councillors become conduits for funnelling bottom-up visions into the RDC level and reporting topdown decisions on such visions to local communities. Such a role reinforces the image of councillors as extensions of the state instead of popular representatives charged with articulating and making decisions in the interests of grassroots communities.

The integrated district plans are sent to the Provincial Council. Plans then enter a tortuous bidding process within the Provincial Development Council, which prioritises them for funding. However, plans that progress beyond this stage are often sidelined in favour of sectoral plans, which are centrally-authored within line ministries (Wekwete and Mlalazi 1990, Thomas 1991). Sectoral planning accords with sectoral budgeting, centrally-directed by the state and traditionally enjoying official favour over decentralised/ territorial budgetary options (Wekwete and Mlalazi 1990). Local plans are thus only tendered as shopping lists which are subject to editing and prioritisation at the district level and further reprioritisation at the provincial level, where they are often sidelined. Local level organisations, therefore, only participate in initiating futile plans but do not in any meaningful way decide, prioritise, fund, or implement the plans. These roles are usually taken over by organisations above them (Wekwete 1990).

Development proposals made by both VIDCOs and WADCOs largely remain on paper because decentralised planning was never considered together with decentralised implementation or decision making (Conyers 1990). These bodies are not legally entitled to raise revenue from their citizens nor do they receive any government funds . Rural District Councils also did not enjoy budgetary autonomy but a new rural development dispensation, associated with structural adjustment programmes in the $1990 \mathrm{~s}$, has imposed cutbacks in state funding to local authorities. In their quest to plug the fiscal gap left by the retracting state, Rural District Councils have increasingly become unwilling to decentralise power and resources (especially financial control) to lower units, resulting in a recentralisation at the district level (Murombedzi 1992). Trickle-down orientations still bedevil most 'decentralised' natural resource management initiatives implemented through Rural District Councils, including the CAMPFIRE programme (Murombedzi 1991, 1992, Campbell et al. in press). The RDC is, nevertheless, the level at which effective decentralisation ends, at least in terms of the legal framework.

Decentralisation in the immediate postindependence period fell under the auspices of a broad reconstruction and development programme ${ }^{16}$ envisaging expanded service and infrastructural investment, especially in the peasant sector (Wekwete 1990). Reconstruction and development were pursued under a policy framework enunciating 'growth with equity'. In practice, there was no parity between the two components of the policy, with the growth thrust lagging behind an equity component that mainly relied on a flow of resources from central government (Wekwete 1990). A complementary policy envisaged the establishment of growth points in rural areas to attract investment and growth based on each region's geographical strengths. The plan never effectively took off because of urban biases in investment priorities and, until now, the growth points are dominated by service-type investment, especially general dealer retail shops, beer halls and bottle stores (Wekwete 1987).

\footnotetext{
${ }^{15}$ English is usually the medium of communication in the RDDCs (Chagonda, E. personal communication-Chief Executive Officer, Chivi Rural District Council).

${ }^{16}$ The agenda fell under the ambit of the Zimbabwe Conference on Reconstruction and Development (ZIMCORD).
} 
By making VIDCOs, WADCOs and RDDCs upwardly accountable, by developing superficial consultation processes, and by providing little financial support for local decision-making, the post-colonial efforts at decentralisation have fallen short of democratising forest governance.

\section{The disempowerment and subsequent courtship of chiefs}

The village and ward development committees existed side by side with the 'traditional' institutions of chief, headman and kraalhead. In practice, the two systems did not have clearly defined mandates and communication processes, and relied on different sources of legitimation (state for VIDCOs WADCOs and customary for traditional villages) making conflict between them inevitable. The formation of VIDCOs and WADCOs was, in fact, part of the disempowerment of 'traditional' institutions process, a measure purportedly adopted to punish chiefs for their pre-independence role as functionaries of colonial oppression (Makumbe 1998). The Communal Lands Act of 1982 had, meanwhile, divested the chiefs of the land allocation powers vested in them in the 1960s. The Communal Lands Act vested control over land in the president and devolved its administration to Rural District Councils and district administrators under the then Ministry of Local Government Rural and Urban Development. Rural District Councils therefore became de jure land authorities, but chiefs and headmen have, in practice, always inserted themselves into the process by clandestinely allocating the land on the basis of customary, territorial and other claims to the land. Spatially, there are overlaps between traditional villages and the VIDCOs and WADCOs (Lynam et al. 1996). The various units are characterised by overlapping and not wholly concordant resource units, memberships and jurisdictions, user-defined interests and uses, and varying degrees of association and affection within and among them, and these vary through time (Sithole 1997, Frost and Mandondo 1999).

A Land Tenure Commission (LTC), tasked with investigating appropriate land tenure and agricultural systems for various parts of the country, was set up in the early 1990s (Government of Zimbabwe 1994). The commission recommended that 'traditional villages' under village heads were the legitimate and appropriate units for local natural resource management in communal areas, and that the villages should be given exclusive legal authority over resources within their areas. The Land Tenure Commission was part of official (political) flirtations with chiefs and allied 'traditional' institutions, spanning from the early 1990s and leading to their formal re-empowerment through the Traditional Leaders Act of 1998. In line with the recommendations of the Land
Tenure Commission the act recognised the 'traditional' village as the lowest unit of social organisation. The act provided for the granting of registration titles to village assemblies that are based on adult village suffrage and presided over by a village head appointed by the chief. A registered village is to consist of a clearly mapped spatial unit with well-defined boundaries. The village assembly, or its headman, share some of the following roles: custodianship and adjudication in respect to cultural matters and people's interests; management of local resources and their use; an electoral role in choosing members of the village development committee; and supervision in respect to consideration and approval of plans from the village development committee before incorporation into ward plans.

Above the village assembly is the ward assembly consisting of all village heads of its constituent village assemblies, a cohort of headmen nominated by chiefs and endorsed by the relevant minister, and the councillor of the ward. The ward assembly is presided over by a headman elected by members of the assembly from among themselves. Ward assemblies oversee all the roles and activities of their constituent village assemblies. In addition to nominating village heads for appointment by the chief and supervising them, headmen are also charged with the enforcement of all environmental planning and conservation by-laws on behalf of the chief, the Rural District Council and the state. Traditional leaders are therefore empowered to enforce rules and exact fines that are siphoned to the Rural District Councils which provides a typical case of higher level authorities decentralising costs but retaining control of benefits. In practice, the efficacy of state-imposed enforcement mechanisms is the outcome of an interaction in which state-imposed enforcement arrangements are reworked through grounded enforcement mechanisms and other factors that are part of everyday social life (Moore 1998, 1999). The portfolio of local enforcement includes: subtle and implicit enticements of the rules that are 'written within the hearts of the people' (moral economy); explicit arrangements such as monitoring and apprehension through headmen and the chief's police; and esoteric tools of monitoring and censure, e.g. spirit mediums and the weight of religious censure (Mandondo 1997). These are, in turn, subject to local contestation and negotiation.

Chiefs are presidential appointees who are tasked to supervise headmen. Their other roles include: promoting and upholding cultural values, especially the extended family; overseeing the collection by village heads of taxes and levies for the Rural District Council; and ensuring land and natural resources are used in accordance with national legislation, especially that prohibiting 'over-cultivation', 'over-grazing' and 'deforestation'. All three provisions are perfect reenactments of the colonial roles of chiefs. 'Upholding 
cultural values' suggests the notion of ambient or canonical cultures that are inviolable and unchanging, but real world 'cultures' are usually plural and dynamic outcomes of contestations and negotiations of interests (Moore 1993). The third provision represents a perfect replay of the command and control philosophy of the 1940s and 1950s in which chiefs featured prominently as colonial functionaries helping enforce top-down legislation in a highly unpopular environmental restoration project. The spirit of rural empowerment is also basically contradicted by the continued use of incriminating labels and alarmist vocabulary (overcultivation, over-grazing, and deforestation) for describing potential environmental change among peasant communities. Such labels often contribute to the elision of the factors in which processes of environmental change among peasant communities are rooted, e.g. imbalances in the distribution of land, and biases in investment priorities.

Chiefs from each province constitute a provincial assembly chaired by a member elected by the chiefs from among themselves. The provincial assembly is essentially a forum for discussing top-down agendas because they are tasked to consider what the minister may sometimes assign them for discussion. Provincial assemblies are also tasked to bring matters of national or local interest to the attention of the minister, a broad, if fuzzy and dubious, mandate. The Traditional Leaders Act effectively disenfranchised grassroots communities in its attempt to re-empower traditional leaders. It created a huge flow of top-down appointments serving only the interests of upward accountability: the president appoints the minister of Local Government and National Housing and the chiefs; the chiefs in turn nominate the headmen, whom the minister appoints; and the headmen nominate the village heads, whom the chief appoints.

Traditional leaders are not elected but appointed from hereditary lineages. Once nominated they normally hold office for life and only the higher offices that appointed them, and not the ordinary majority, have the prerogative of divesting them of their power. Native commissioners used to appoint chiefs during the colonial era. The Traditional Leaders Act reinforced the overcentralisation of the appointment of traditional leaders as chiefs and headmen are appointed by the far higher offices of president and minister respectively. Chiefs were heavily represented in the composition of the Land Tenure Commission, which was appointed by the president (Moyo 1996a). This may have given them an unfair advantage over other sections of society in defining the shape and form of powers eventually vested in them through the Traditional Leaders Act. It is evident from the foregoing analysis that democratic considerations did not feature highly in the empowerment of chiefs. Chiefs were, most probably, courted to shore up sagging political fortunes. The temptation to rush to empower chiefs should have been politically exciting given that a broad and extended inquiry had declared them 'appropriate and legitimate'. The state seized the opportunity to move quickly to incorporate an important, but hitherto alienated, political constituency. The Machiavellian strand in the new wave of flirtations between the state and chiefs is betrayed by the array of real and potential privileges for the chiefs. By nothing other than the virtue of their breed and perceived importance as sources of political mileage, chiefs now earn a salary equivalent to that of a university graduate and extra benefits, e.g. special transport, have already been pledged. At the national level chiefs are represented by a Council of Chiefs and have 10 seats allocated within the country's 150 -seat legislature.

Legitimacy forms the central plank of the Land Tenure Commission's argument for the empowerment of 'traditional' institutions, despite the fact that the Commission's findings are not backed by a clear set of criteria on which this objective function was assessed. The fact is that, in principle, Zimbabwe now has three formal hierarchies spanning from the state to the grassroots: a customary chiefly system enjoying the LTC seal of 'legitimacy'; a multisectoral hierarchy of government ministries; and a local government councillor-Rural District Council system. Why the three systems should exist side by side at enormous cost to the taxpayer, is a question that the Commission and the crafters of the Traditional Leaders Act have evaded. In practice the three hierarchies fall into the following combinations with regards to grassroots representation and accountability: a local government hierarchy championing representation (councillor) without effective accountability to the peasant communities; a hereditary and non-elected hierarchy of chiefly and village head nominees; and a non-representative sectoral hierarchy that usually channels top-down plans to peasant communities. Sectoral plans and visions often derive their strength and dominance from the marginalisation, weakening and incrimination of local visions, practices and ways of thinking (Shiva 1987, Matowanyika 1991).

The three hierarchies fan out, at the local level, into several administrative, developmental, social, political and other bodies adding to the numbers of those that already exist (Sithole 1997). External NGOs, particularly those championing empowerment and participation under the broad umbrella of the 'international back to the people' crusade, also add to the numbers. Overall, although the various organisations often have overlapping but non-concordant memberships, goals, strategies and interests, most share certain features. Most make competing demands for the peasant's time, effort, skills, resources, etc. All champion peasant improvement through a variety of development narratives 
expressed in various fashion terms often describing the same thing: satisfying basic needs; enhancing food security and self-sufficiency; disaster relief; putting people first; looking beyond farmer-first; understanding the politics of culture; giving people an active voice, privileging local forms of thought and perception; leadership training and training for transformation; participatory monitoring for adaptive comanagement; joint forest management; participatory action research; participatory experimentation; on farm experimentation; visioning and scenario building; capacity building and enhancement; social learning, etc. Fashion formulations carry a cutting-edge appeal that easily gets the seal of peer approval in powerful professional socialisations, and the generation of new and catchy formulations is part of an industry of steering on course the funding trail (Byron 1997). The whole process reinforces top-down orientations since most of the projects are defined according to the terms and processes of external agents, usually the funders of the projects and their intermediaries and functionaries (Byron 1997), including this author.

\section{Discussion}

The foregoing analyses show that despite rhetoric implying decentralised structures and arrangements such decentralisation can have very little to do with democratisation of forest management. For instance, indirect rule was about extending the power of the central state, although it was justified in terms not unlike those advocating decentralisation today: respect of local cultures, fiscal accountability and giving people a voice in their own governance. The quest to extend the power of the central state led to over-centralisation of power and control over natural resources in peasant areas. Local government reform in post-colonial period neither genuinely decentralised nor democratised resource governance and it appears to have been designed to entrench one-party political domination. Post-colonial amendments to over-centralised controls on peasant access and use of natural resources have largely deracialised the regulatory frameworks without democratising them. Most acts still feature the criminalising, and command and control postures and approaches of their colonial antecedents (cf. Mamdani 1996). Natural resource governance systems have thus, by and large, resulted in weakening of the peasant stake in access, use and control of natural resources, from colonial through to post-colonial times.

Various strands of peasant disempowerment are evident. The first form is reflected through structures that deny peasant communities accountable forms of representation. For instance, the 'traditional' chiefly institutions were founded on the undemocratic principle of fusion of legislative, executive and judiciary powers.
Although the creation and reinforcement of such structures ran on the pretext of building on the legitimacy of existing structures, their design enhanced racial domination and ascendency of colonial administration resulting in a decentralised despotism (Mamdani 1999). Over the years chiefly institutions have been used to legitimise external (mostly state) agendas that further weakened the peasantry, including the extension of the state's influence or reviving its political mileage. Chiefly institutions existed in tandem with new institutions, created by the state in the immediate post-independence period, ostensibly to democratise the process of planning for local development but also serving to further the interests of one-party political domination.

The second form of disempowerment has been through the over-centralisation of power and decisionmaking in environmental regulation systems. A trend towards concentrating power in the executive, especially the presidency and bureaucracies under executive direction, was entrenched from colonial through to postcolonial times. Despite aspirations of extending farreaching control, the state and its bureaucracies lack the resources and capacity to effectively enforce most controls (Vermeulen 1994). Third, over-centralisation was justified through yet another form of disempowerment associated with discourses of 'science' that justified a command and control approach to environmental regulation. The peremptory approach to environmental regulation was inherited piecemeal into post-colonial times, in which later amendments fell far short of democratising the regulation systems. A fourth and procedural form of disempowerment occurs through the use of alienating languages in certain forums such as the RDDC and decision-making frameworks that override the visions of lower constituencies. Fifth, there is fiscal disempowerment through urban biases in investment priorities, externalisation of locally collected revenues and also through the burdens imposed upon taxpayers by a multiplicity of bloated organisational hierarchies. Lastly, there is a generalised disempowerment associated with presence at the local level of many organisations, essentially sharing the same broad goals but with different and often 'predetermined' visions of how, when, for whom and through whom to achieve them.

Most forms of disempowerment inherent in Zimbabwe's natural resource governance systems reflect the dangers of supply-led decentralisation in which states enjoy a free reign in defining governance systems and the nature and extent of the entrustments to be devolved to local communities (cf. Agrawal and Ribot, forthcoming). There appears to be general reluctance on the part of the state to decentralise meaningful entrustments to local communities. Supply-led decentralisation, therefore, needs to be complemented by demand-driven decentralisation, conceivably 
championed by civil society. There is, nevertheless, a general absence of a vibrant civil society or social movements championing genuinely democratised natural resource governance, particularly from the local settings. Incremental rather than piecemeal strategies could, therefore, provide the most appropriate and least costly entry-points to engaging the state and other external actors to democratise natural resource governance. The initial front of engagement could include advocacy for transparency and accountability within the framework of supply-led decentralisation, for instance through: providing information to peasant communities on the structure and function of governance structures, emphasising potential areas of local empowerment; ensuring that there is effective participation during bylaw formulation at RDC level; ensuring that communities are effectively consulted before the by-laws are approved; lobbying for transparent and timely disbursement of CAMPFIRE revenues to local communities; lobbying for more community representatives in the RDDC and helping community representatives in the Rural District Council to demand that the RDDC reports and is accountable to council; advocating that Rural District Councils demand greater coordination among research, development and advocacy organisations working within their areas; and intervening at ministry, cabinet and national assembly levels to ensure that local interests are taken into consideration during the preparation of legislation having implications on natural resource governance.

As civil society and advocacy movements gain strength the agenda could be broadened to include advocating reforms in governance structures and arrangements, which could include some of the following: pushing for rationalisation of the dual VIDCOWADCO and the chief-headman systems to avoid the administrative confusion of bloated and costly hierarchies; demanding that the adopted system genuinely embraces democratic principles of representation and entrustment instead of customary or political fiat; arguing for genuinely democratic and accountable representation in local government; advocating conferment of appropriate authority status to user-defined groups below the district level and localisation of environmental fines' collection with royalties going to the council; and advocating legislative reform to ensure that local communities access the benefits. If civil society organisations multiply they could specialise along advocacy mandates as they develop but this will require coordination. Such coordination should also help prevent corruption and hijacking of civil society agendas by the state and other external interests, as discussed and reported by Fatton (1995) and Holm et al. (1996), respectively.
An incremental approach should conceivably be tactical, consolidating meaningful entrustments already secured for the community, or its most disadvantaged sectors, whilst advocating the expansion of existing sets of entrustments. For example, Zimbabwe's flagship for peasant empowerment in natural resource management is the CAMPFIRE programme. A huge body of literature has since accumulated on both the challenges (Murombedzi 19901991 1994, Nhira 1994, Madzudzo 1999) and strengths (Murphree 1990, 1991, 1992, Peterson 1991, King 1994) of the CAMPFIRE programme. Both sides of the literature offer an invaluable resource from which to draw lessons for building on the strengths of the programme. Most decentralisation initiatives, including CAMPFIRE, are nevertheless being implemented within a broader, national, political economy of racial inequities in the distribution of land (Moyo et al. 1991, Moyo 1996b). They therefore carry the stigma of 'delaying tactics' or 'diversionary pursuits' to the more fundamental question of land redistribution, which represents potentially the most important direction towards genuine empowerment of local communities. Although land reform will address some problems of governance through more equitable access to natural resources, current experiences in Zimbabwe show that it is usually 'preached' for political ends and rarely practised. Where practised it is either gradualist and inequitable or rapid and irrational. The former has largely resulted in an intra-class transfer of entrustments over land, from rich white to rich black, over the past twenty years. The latter is the unfolding land grab, running under the guise of addressing racial imbalances but decidedly meant to shore up sagging political fortunes. The major challenge of the unfolding land drama to civil society is the high polarisation and the politically charged nature of the issue.

Community-based or CAMPFIRE-type approaches are also premised on the deep green ethos and values of a global (western) environmental discourse and scientific culture, that is, participation for environmental conservation. Decentralisation conceptualised within the framework of that culture is supply-led, guided by that culture's values and inherently top-down. That culture, being insular, domineering and conditional, offers limited space to 'think' alternative forms of empowerment without green strings attached. It conceptualises community empowerment in the instrumental mode, that is, participation for environmental conservation. The paradigm draws inspiration from the Malthusian logic of static sustainability thresholds on how populations and their consumption levels relate to the environment. The challenge to civil society is to demand decentralisation on the terms and definitions of beneficiary communities. 


\section{Acknowledgements}

This report was compiled under a Center for International Forestry Research initiative called Stakeholders and Biodiversity in the Forests of the Future funded by the Swiss Agency for International Cooperation. The work was conducted in association with the project Zimbabwe: Micro-catchment and Common Property Resources (R7304) funded by the Department for International Development of the United Kingdom. It was written at the University of California, Berkeley, under the Ford Foundation Environment and Culture Residential Fellowship Program tenable under the Environmental Politics Program at the Institute of International Studies. I am most grateful to Donald Moore and David Edmunds for commenting on an earlier version of the paper.

\section{References}

Agrawal, A. and Gibson, C.C. 1999. Enchantment and disenchantment: the role of community in natural resource conservation. World Development 27: 629649.

Agrawal, A. and Ostrom, E. 1999. Collective action, property rights, and devolution of forest and protected area management. Paper to Workshop on Devolution of Natural Resource Management. Puerto Azul, Philippines, 21-25 June 1999.

Agrawal, A. and Ribot, J. forthcoming. Accountability in decentralization: a framework with South Asian and West African cases. Journal of Developing Areas.

Beach, D.N. 1980. The Shona and Zimbabwe, 900-1850: an outline of Shona history. African Publishing Company, New York.

Beinart, W. 1984. Soil erosion, conservationism and ideas about development: a Southern African exploration 1900-1960. Journal of Southern African Studies 11: 52-83.

Berkes, F. and Farvar, M.T. 1989. Cooperation from the perspective of human ecology. In: Berkes, F. (ed.) Common property resources: ecology and community based sustainable development, 1-17. Belhaven Press, London.

Berry, S. 1989. Social institutions and access to resources. Africa 59: 41-55.

Berry, S. 1993. No condition is permanent: the social dynamics of agrarian change in sub-Saharan Africa. University of Wisconsin Press, Madison.

Bhebe, N. 1979. Christianity and traditional religions in western Zimbabwe. Longman, London.

Bourdillon, M.F.C. 1991. Religion and society: a text for Africa. Mambo Press, Gweru.

Byron, N. 1997. International development assistance in forestry and land management: the process and the players. Commonwealth Forestry Review 76: 61-67.
Campbell, B.M., de Jong, W., Luckert, M., Mandondo, A., Matose, F., Nemarundwe, N. and Sithole, B. (in press). Challenges to proponents of CPR systems despairing voices from the social forests of Zimbabwe.

Catholic Commission on Peace and Justice 1992. The Bende Gap people. Catholic Commission on Peace and Justice in Zimbabwe, Harare.

Child, B. 1993. Zimbabwe's CAMPFIRE programme: using the high value of wildlife recreation to revolutionize natural resource management in communal areas. Commonwealth Forestry Review 72: 284-296.

Conyers, D. 1990. Decentralization and development planning: a comparative perspective. In: de Valk, P. and Wekwete, K.H. (eds.) Decentralization for participatory planning?, 15-33. Gower Publishing Company, Aldershot.

Crook, R.C. and Manor, J. 1998. Democracy and decentralization in South Asia and West Africa: participation, accountability and performance. Cambridge University Press, Cambridge.

de Valk, P. 1990. State, decentralization and participation. In: de Valk, P. and Wekwete, K.H. (eds.) Decentralization for participatory planning?, 3-14. Gower Publishing Company, Aldershot.

Dzingirai, V. 1995. Take back your CAMPFIRE: a study of local level perceptions to electric fencing in the framework of Binga's CAMPFIRE. Centre for Applied Social Sciences, University of Zimbabwe, Harare.

Fairhead, J. and Leach, M. 1995. False forest history, complicit social analysis: rethinking some West African environmental narratives. World Development 23: 1023-1035.

Fatton, R. Jr. 1995. Africa in the age of democratization: the civic limitations of civil society. African Studies Review 38: 67-99.

Fortmann, L. and Nabane, N. 1992. The fruits of their labour: gender, property and tree resources in Mhondoro District. Centre for Applied Social Sciences, University of Zimbabwe, Harare.

Frost, P.G.H. and Mandondo, A. 1999. Improving rural livelihoods in semi-arid regions through management of micro-catchments. Institute of Environmental Studies, University of Zimbabwe, Harare.

Godwin, P. 1996. Mukiwa: A white boy in Africa. Harper Perennial, New York.

Grant, P.M. 1976. Peasant farming on infertile sands. Rhodesia Science News 10: 252-254.

Government of Zimbabwe. 1994. Report of the Commission of Inquiry into Appropriate Agricultural Land Tenure Systems. Government Printer, Harare. 
Gupta, A. 1999. Blurred boundaries: the discourse of corruption, the culture of politics, and the imagined state. American Ethnologist 22: 375-402.

Hasler, R. 1993. Political ecologies of scale and multitiered co-management of Zimbabwean wildlife resources under CAMPFIRE. Centre for Applied Social Sciences, University of Zimbabwe, Harare.

Hawkes, R. and Madzudzo, E. 1991. Some observations on the development of a natural resource management project to September 1991. Unpublished paper. Centre for Applied Social Sciences, University of Zimbabwe, Harare.

Helmsing, A.H.J. 1991. Transforming rural local government: Zimbabwe's post-independence experience. In: Mutizwa-Mangiza, N.D. and Helmsing, A.H.J. 1991. Rural development and planning in Zimbabwe, 444-481. Gower Publishing Company, Aldershot.

Hesseling, G. 1996. Legal and institutional incentives for local environmental management. In: Marcussen, H.S. (ed.) Improved natural resource management: the role of formal organizations and informal networks and institutions, 98-134. IDS Discussion Paper 17. Roskilde University, Denmark.

Holleman, J.F. 1968. Chief, council and commissioner. Koninkelijke Van Gorcum, Netherlands.

Holm, J.D., Molutsi, P.P. and Somolokae, G. 1996. The development of civil society in a democratic state: the Botswana model. African Studies Review 39: 4369.

Hyden, G. and Bratton, M. (eds.) 1992. Governance and politics in Africa. L. Rienner, Boulder.

International Union for the Conservation of Nature and natural Resources (IUCN). 1980. World conservation strategy: living resource conservation for sustainable development. IUCN, Gland.

International Union for the Conservation of Nature and natural Resources (IUCN). 1991. Caring for the earth: a strategy for sustainable living. IUCN, Gland.

Jackson, J.C. 1989. Exploring livestock incomes in Zimbabwe's communal lands. In: Cousins, B. (ed.) People, land and livestock in the communal lands of Zimbabwe: proceedings of a Workshop on the Socioeconomic Dimensions of Livestock Production in Communal Lands of Zimbabwe, 183-200. GTZ and Centre for Applied Social Sciences, University of Zimbabwe, Harare.

King. L.A. 1994. Inter-organisational dynamics in natural resource management: a study of CAMPFIRE implementation in Zimbabwe. Centre for Applied Social Sciences, University of Zimbabwe.

Lan, D. 1985. Guns and rain: guerillas and spirit mediums in Zimbabwe. James Currey, London.

Li, T.M. 1999. Images of community: discourse and strategy in property relations. Development and Change 27: 501-527.

Lynam, T.J.P., Chitsike, J., Howard, M., Hodza, P., Khumalo, M.A. and Standa-Gunda, W. 1996. Assessing the contributions of renewable natural resources to the livelihoods of communal area households in the Zambezi Valley of Zimbabwe. Paper presented to the Pan-African Symposium on Sustainable Use of Natural Resources and Community Participation, 24-27 June 1996. Harare, Zimbabwe.

Madzudzo, E. 1999. Incentives, interest groups and enterprise development in Zimbabwe's CAMPFIRE Programme. WWF (Southern African Regional Programme Office), Harare.

Makumbe, J. Mw. 1996. Participatory development: the case of Zimbabwe. University of Zimbabwe Publications, Harare.

Makumbe, J. Mw. 1998. Democracy and development in Zimbabwe: constraints of decentralization. SAPES Trust, Harare.

Mamdani, M. 1996. Citizen and subject: contemporary Africa and the legacy of late colonialism. Princeton University Press, Princeton.

Mamdani, M. 1999. Historicizing power and responses to power: indirect rule and its reform. Social Research 66: 859-884.

Mandondo, A. 1997. Trees and spaces as emotion and norm laden components of local ecosystems in Nyamaropa communal lands, Nyanga District; Zimbabwe. Agriculture and Human Values 14: 352372.

Manungo, K.D. 1991. The peasantry in Zimbabwe: a vehicle for change. In: Kaarlsholm, P. (ed.) Cultural struggle and development in Southern Africa, 115123. James Currey, London.

Marcussen, 1996. The critical issue of state-society relations. In: Marcussen, H.S. (ed.) Improved natural resource management: the role of formal organizations and informal networks and institutions, 2-29. IDS Occasional Paper 17. Roskilde University, Denmark.

Marindo-Ranganai, R. and Zaba, B. 1995. Animal conservation and human survival: a case study of the Tembomvura people of Chapoto Ward in the Zambezi Valley, Zimbabwe. Centre for Applied Social Studies, University of Zimbabwe, Harare.

Mashingaidze, E.K. 1984. From Iron Age to independence: a history of Central Africa. Longman, Harrow.

Matowanyika, J.Z.Z. 1991. Indigenous resource management and sustainability in rural Zimbabwe: an exploration of practices and concepts in commonlands. Ph.D. thesis, University of Waterloo, Ontario. 
Matzke, G.E. 1993. Resource sharing schemes from state-owned land in Zimbabwe: a discussion of conceptual issues. Centre for Applied Social Sciences, University of Zimbabwe, Harare.

McCay, B.J. and Acheson, J.M. 1987. Human ecology of the commons. In: McCay, B.J. and Acheson, J.M. (eds.) The question of the commons: the culture and ecology of communal resources, 1-34. University of Arizona Press, Tucson.

McGregor, J. 1991. Ecology, policy and ideology: an historical study of woodland use and change in Zimbabwe's communal areas. Ph.D thesis, Loughborough University of Technology.

McGregor, J. 1995. Conservation, control and ecological change: the politics and ecology of colonial conservation in Shurugwi, Zimbabwe. Environment and History 1: 257-279.

McNeely, J.A. 1995. Partnerships for conservation: an introduction. In: McNeely, J A. (ed.) Expanding partnerships in conservation, 1-12. Island Press, Washington D.C.

Medard, J.F. 1996. Patrimonialism, neopatrimonialism and the study of the post-colonial state in sub-Saharan Africa. In: Marcussen, H.S. (ed.) Improved natural resource management: the role of formal organizations and informal networks and institutions, 76-97. IDS Occasional Paper 17. Roskilde University, Denmark.

Meinzen-Dick, R. and Knox, A. 1999. Collective action, property rights, and devolution of natural resource management, a conceptual framework. Paper to Workshop on Devolution of Natural Resource Management. Puerto Azul, Philippines, 21-25 June 1999.

Metcalfe, S. 1995. Livestock, wildlife and the forage commons: prospects for rangeland reform in a semiarid communal area of Zimbabwe. Centre for Applied Social Sciences, University of Zimbabwe, Harare.

Moore, D.S. 1993. Contesting terrain in Zimbabwe's Eastern Highlands: political ecology, ethnography, and peasant resource struggles. Economic Geography 69: 380-401.

Moore, D.S. 1996. A river runs through it: environmental history and the politics of community in Zimbabwe's Eastern Highlands. Centre for Applied Social Sciences, University of Zimbabwe, Harare.

Moore, D.S. 1998. Subaltern struggles and the politics of place: re-mapping resistance in Zimbabwe's Eastern Highlands. Cultural Anthropology 13: 344381 .

Moore, D. S. 1999. The crucible of cultural politics: reworking 'development' in Zimbabwe's Eastern Highlands. American Ethnologist 26: 1-36.
Moyo, S. 1996a. Land and democracy in Zimbabwe. Paper presented to the International Historical Dimensions of Democracy and Human Rights. University of Zimbabwe History Department, Harare.

Moyo, S. 1996b. The land question in Zimbabwe. Southern Africa Regional Institute for Policy Studies. SAPES Books, Harare.

Moyo, S., Robinson, P.; Katerere, Y.; Stevenson, S. and Gumbo, D. 1991. Zimbabwe's environmental agenda: balancing resource inequities. ZERO, Harare.

Muchena, M. 1989. The effect of ox-sharing arrangements on the supply and use of draught power animals in communal areas of Zimbabwe preliminary findings. In: Cousins, B. (ed.) People, land and livestock in the communal lands of Zimbabwe: proceedings of a Workshop on the Socioeconomic Dimensions of Livestock Production in Communal Lands of Zimbabwe, 253-277. GTZ and Centre for Applied Social Sciences, University of Zimbabwe, Harare.

Mukamuri, B.B. 1995. Making sense of forestry: a political and contextual study of forestry practices in rural Zimbabwe. Ph.D. thesis. University of Tampere, Finland.

Murombedzi, J. 1991. Decentralising common property resources management: a case study of the Nyaminyami District Council of Zimbabwe's wildlife management programme. IIED Paper No. 30. IIED, London.

Murombedzi, J.C. 1992. Decentralization or recentralization? - implementing CAMPFIRE in the Omay Communal Lands of the Nyaminyami District. Centre for Applied Social Sciences, University of Zimbabwe, Harare.

Murombedzi, J.C. 1994. The dynamics of conflict in environmental management policy in the context of CAMPFIRE. Ph.D thesis. University of Zimbabwe, Harare.

Murphree, M.W. 1990. Decentralizing the proprietorship of wildlife resources in Zimbabwe's communal areas. Centre for Applied Social Sciences, University of Zimbabwe, Harare.

Murphree, M.W. 1991. Communities as institutions for resource management. Centre for Applied Social Sciences, University of Zimbabwe, Harare.

Murphree, M.W. 1992. Participation or proprietorship: the central issue. Draft paper outline for discussion during the WWF workshop on "People, Parks and Participation: Creating Effective Linkages". Belagio, 24-28 August 1992.

Murphree, M.W. 1999. Enhancing sustainable use: incentives, politics and science. Berkeley Workshop on Environmental Politics. Working Paper 2/99. Institute of International Studies, University of California, Berkeley. 
Murphree, M.W. and Cumming, D.H.M. 1991. Savanna landuse policy and practice in Zimbabwe. Paper presented at the UNESCO/IUBS Conference on Savanna Landuse. Nairobi, January 1991.

Mutizwa-Mangiza, N.D. 1985. Community development in pre-independence Zimbabwe: a study of policy with special reference to rural land. Supplement to Zambezia.

Mutizwa-Mangiza, N.D. 1991. Decentralization in Zimbabwe: problems of planning at the district level. In: Mutizwa-Mangiza, N.D. and Wekwete, A.H.J. (eds.). Rural development and planning in Zimbabwe, 418-443. Gower Publishing Company, Aldershot.

Nhira, C. 1994. Zimbabwe's CAMPFIRE programme as an example of a co-management initiative. Centre for Applied Social Sciences, University of Zimbabwe, Harare.

Nhira, C. 1998. Landuse planning and woodland management: a case study of local control and regulatory capacity on household and communal woodland resources in Zimbabwe. IES Working Paper 8. Institute of Environmental Studies, University of Zimbabwe, Harare.

Nhira, C. and Matose, F. 1995. Lessons for the resource sharing project in Zimbabwe from the Indian joint forest management and CAMPFIRE programmes. Centre for Applied Social Sciences, University of Zimbabwe, Harare.

Nhira, C., Baker, S., Gondo, P., Mangono, J.J. and Marunda, C. 1998. Contesting inequality in access to forests: policy that works for forests and people. Centre for Applied Social Sciences and Forestry Commission, Harare and International Institute of Environment and Development, London.

Ostrom, E. 1990. Governing the commons: institutions for collective action. Cambridge University Press, Cambridge.

Ostrom, E. and Schlager, E. 1996. The formation of property rights. In: Hanna, S., Folke, C. and Maler, K.G. (eds.) Rights to nature: ecological, economic, cultural and political principles of institutions for the environment, 127-156. Island Press, Washington D.C.

Peterson, J.H. 1991. CAMPFIRE: a Zimbabwean approach to sustainable development and community empowerment through wildlife utilization. Centre for Applied Social Sciences, University of Zimbabwe, Harare.

Phimister, I. 1988. An economic and social history of Zimbabwe 1890-1948: capital accumulation and class struggle. Longman, London.

Pomeroy, R.S. 1999. Devolution in fisheries comanagement. Paper to Workshop on Devolution of Natural Resource Management. Puerto Azul, Philippines, 21-25 June 1999.
Price, L. and Campbell, B.M. 1998. Household tree holdings: a case study in Mutoko communal area, Zimbabwe. Agroforestry Systems 39: 205-210.

Ribot, J.C. 1998. Theorizing access: forest profits along Senegal's charcoal commodity chain. Development and Change 29: 307-341.

Ribot, J.C. 1999a. Decentralization, participation and accountability in Sahelian forestry: legal instruments of political-administrative control. Africa 69: 23-65.

Ribot, J.C. 1999b. Integral local government: authority, accountability and entrustment in natural resource management. Regional Program for the Traditional Energy Sector. World Bank, Washington D.C.

Schilling, T. 1995. Subsidiarity as a rule and a principle, or: taking subsidiarity seriously. Harvard Law School, Harvard.

Schroeder, R. 1999. Geographies of environmental intervention in Africa. Progress in Human Geography 23: 359-378.

Scoones, I. 1996. Politics, polemics and pasture in Southern Africa. In: Leach, M. and Mearns, R. (eds.) The lie of the land: challenging received wisdom on the African environment, 34-53. James Currey, Oxford and Heinemann, New Hampshire.

Scoones, I. and Matose, F. 1993. Local woodland management: constraints and opportunities for sustainable resource use. In: Bradley, P.N. and McNamara, K. (eds.) Living with trees: policies for woodland management in Zimbabwe, 157-198. World Bank, Washington, D.C.

Scoones, I., Chibudu, C., Chikura, S., Jeranyama, P., Machaka, D., Machaya, W., Mavedzenge, B., Mombeshora, B., Mudhara, M., Mudziwo, C., Murimbarimba, F. and Zirereza, A. 1996. Hazards and opportunities: farming livelihoods in dryland Africa, lessons from Africa. ZED Books, New Jersey.

Shipton, P. and Goheen, M. 1992. Understanding African landholding: power, wealth and meaning. Africa 62: 307-325.

Shiva, V. 1987. The violence of reductionist science. Alternatives 12: 243-261.

Sithole, B. 1997. The institutional framework for the management and use of natural resources in the communal areas of Zimbabwe: village cases of access to and use of dambos from Mutoko and Chiduku. Centre for Applied Social Sciences, University of Zimbabwe, Harare.

Thomas, S.J. 1991. The legacy of dualism in decision making: the prospects for local institutional development in CAMPFIRE. Centre for Applied Social Sciences, University of Zimbabwe, Harare.

Thomson, J.T. and Freudenberger, K.S. 1997. Crafting institutional arrangements for community forestry. 
Community Forestry Field Manual 7. Food and Agriculture Organization, Rome.

United Nations Environment Programme (UNEP). 1992. Convention on biological diversity. UNEP, Nairobi,

Vermeulen, S.J. 1994. Consumption, harvesting and abundance of wood along the boundary between Mafungautsi and Gokwe Communal Area, Zimbabwe. M.Sc thesis. University of Zimbabwe, Harare.

Vermillion, D.L. 1999. Property rights and collective action in the devolution of irrigation system management. Paper to Workshop on Devolution of Natural Resource Management. Puerto Azul, Philippines, 21-25 June 1999.

Weinrich, A.K.H. 1971. Chiefs and councils in Rhodesia: transition from patriarchal to bureaucratic power. University of South Carolina Press, Columbia.
Wekwete, K.H. 1987. Growth centre policy in Zimbabwe. Occasional paper 7. Department of Rural and Urban Planning, University of Zimbabwe, Harare.

Wekwete, K.H. 1990. Constraints to planning for socialism in Zimbabwe. In: de Valk, P. and Wekwete, K.H. (eds.) Decentralization for participatory planning?, 37-51. Gower Publishing Company, Aldershot.

Wekwete, K.H. and Mlalazi, A. 1990. Provincial/regional planning in Zimbabwe: problems and prospects. In: de Valk, P.and Wekwete, K.H. (eds.) Decentralization for participatory planning?, 86-98. Gower Publishing Company, Aldershot.

World Commission on Environment and Development (WCED). 1987. Our common future. Oxford University Press, Oxford.

Zvobgo, C.J.M. 1996. A history of christian missions in Zimbabwe 1890-1939. Mambo Press, Gweru. 